\title{
IMPACT OF FOREIGN DIRECT INVESTMENT, EXTERNAL DEBT AND POPULATION ON ECONOMIC GROWTH OF PAKISTAN: 1980-2014
}

\author{
Shoukat Ali \\ M.Athar Hussain ${ }^{* *}$ \\ Aqsa Zulqaif ${ }^{* * *}$
}

\begin{abstract}
This study aims to analyze the impact of Foreign Direct Investment(FDI), external debt and population growth on economic progress of Pakistan by using time series data from 1980 to 2014. It analyzes the correlation between Gross Domestic Product(GDP),FDI, external debt and population growth. Augmented Dickey Fuller test has been used to check stationarity in time series data. To evaluate the empirical results multiple regression method is used. GDP has been used as a dependent variable while FDI, external debt and population as independent variables. Findings of this paper show the positive and significant impact of FDI, and population growth on GDP but external debt has negative impact on GDP.
\end{abstract}

Keywords: FDI, GDP, external debt, population growth

\section{Introduction}

Foreign direct investment is most important and effective indicator for influx of external resources all over the world. In developing countries, the foreign direct investment has become a significant feature for building capital all around the world. But it is observed that the trends of foreign direct investment in developing countries from other states was declined over the past years. The significance and importance of FDI can be recognized from the fact that it can be used as a tool of the economic growth because it leaves positive and significant impact on economic development of a country. ${ }^{1}$ The foreign direct investment has played most important and significant role to boost up aggregate demand, increased employment opportunities, enhanced exports and technological exchange between the countries.

Main aim of this research is to examine the effect of foreign direct investment, population and external debt on gross domestic product of the Pakistan from 1980 to 2014 by using time series data. Now a days FDI is very important indicator for any

"Shoukat Ali, Lecturer, Department of Commerce, The Islamia University of Bahawalpur, R.Y.Khan Campus, Pakistan

${ }^{* *}$ M.AtharHussain, Ph.D. Lecturer, Department of Education, The Islamia University of Bahawalpur, R.Y.Khan Campus, Pakistan

${ }^{* * *}$ Aqsa Zulqaif, Research Student, Department of Economics, The Islamia University Of Bahawalpur, R.Y.Khan Campus, Pakistan

${ }^{1}$ Waheed, Muhammad, Central Bank Intervention, Sterilization and Monetary Independence: The Case of

Pakistan, MPRA Paper 2328, (Germany: University Library of Munich, revised Mar 2007) 
economy because FDI plays leading role in the growth of an economy. Output of any country consists of consumption, investment and government expenditure. Such investment contains domestic and foreign investment. This study uses GDP as dependent variable and FDI, population growth rate and external debt as independent variables. Here GDP is the proxy of economic growth of host country. This indicates the monetary worth of all final goods and services produced within the boundaries of a country in a given period. Xiaohong (2009) conducted a study on GDP, FDI and external debt in China. He gathered data from 1985 to 2008 to find benefits of using FDI and its impact on GDP in China. He found that FDI is better for China because FDI has positive and significant impact on economic growth of China. ${ }^{2} \mathrm{On}$ the other hand external debt and GDP are negatively related to each other.

Pakistan's economy has faced solemn troubles due to deficit in the revenue account of federal budget for the last three decades. The revenue account showed a small surplus before 1969-70 available to finance capital account. The resource crack could then be crammed through additional taxation or borrowing. This condition went on deteriorating afterward. This situation compelled the government to finance the deficit in budget through internal and external borrowing and deficit financing. These actions put the burden of large debt and debt service on Pakistan. Further this situation has given future of the economy in the hands of donor agencies (Yaseen,2001). ${ }^{3}$ The budget speech by the Federal Finance Minister(2001-2002) has explained this situation as:

\begin{abstract}
Our basic trouble in actual is that our resources are less than our expenditures. Our main resources are tax and non-tax revenues, such revenues are not significantly enough to fulfill such extra expenditures. In ancient times it was quite easy to meet surplus expenditures because at that time borrowed money was fixed only for development expenditures. But our investment gives not good proceeds and there are no alternative ways for extracting more revenues. Nowa days, deficit arises because non development expenditures are also meet up through borrowings. Circumstances are that now debt services and salaries are paid through borrowings. Such a progression cannot last common logic for long. It is the sign of unfavorable circumstances for an economy. This can also be explained as budget deficit. Budget becomes deficit when imports of one country become lower than the exports of such country. There is a need for one country to maximize its exports and induce foreign direct investment to meet this problem. ${ }^{4}$
\end{abstract}

Saqib, Masnoon and Rafique (2013) examined the impact of foreign direct investment on economic progress of the host country. Conclusion of this study at the context of the economic performance of Pakistan revealed that foreign investment affects economic growth negatively, while its domestic investment has affected positively to the country's

\footnotetext{
${ }^{2} \mathrm{Ma}$, Xiaohong (2009). An Empirical Analysis on the Impact of FDI on China'sEconomic Growth. International Journal of Business and Management, 4(6), 76-80.

${ }^{3}$ Yasin, M. (2001). The debt crises of Pakistan and an optimal fiscal policy. Pakistan Economic and Social Review, 39(2), 153-186

${ }^{4}$ Saeed, Prof Dr Amjad Khawaja, http://www.pakistaneconomist.com/issue2001/issue36/i\&e4.htm (accessed in July 2016)
} 
economic performance. ${ }^{5}$ On the other hand, the nation's external debt, trade and inflation have negative influence on its Gross domestic product.

According to Julian and Simon (1992), population growth and economic development of less developing countries have a long run correlation. This study shows a positive relationship between population growth and economic development because growth in population increases number of consumers. This leaves a positive impact on economic growth and development of such economy. ${ }^{6}$

Kothare (1999) constructed a model which used the effects of demand on investment, the choice between leisure and work as a function of living standards and difference in needs along with economies of scale. This model is used to solve the theory of utility maximization, or can be used to find the highest leisure-output indifference curve. This IC makes a tangent to a production function like $(\mathrm{Q}=\{\mathrm{L}, \mathrm{T}, \mathrm{K}\})^{7}$

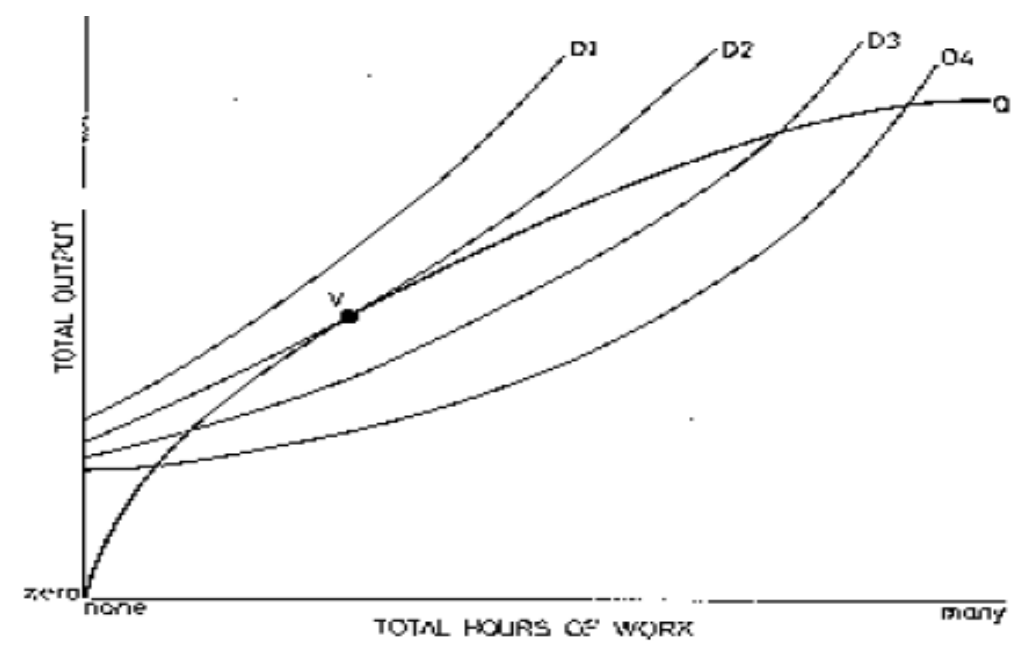

Source: Kothare (1999)

In above mentioned diagram, we can easily see that the production function is based on working hours and output. Maximum utility can be achieved by maximizing employment. By using different parameters it indicates that economic performance will be better and positive if population growth will be positive.

Dunning and Hamdani(1997) used GDP as explained variable and FDI, population, and external debt as explanatory variables. The most positives of implementing FDI in

${ }^{5}$ Saqib, N., Masnoon, M., and Rafique, N. (2013). Impact of Foreign Direct Investment on Economic Growth of Pakistan. Advances in Management \& Applied Economics, 3(1), 35-45

${ }^{6}$ Simon, J. L. (1992).Population and Development in Poor Countries. Princeton: Princeton University Press.

${ }^{7}$ Kothare, R. (1999). Does India's Population Growth Has A Positive Effect on Economic Growth? Social

Science 410 
developing countries is the increase in aggregate production, increase in population opportunities, more exports and transfer of technical advancement with investors. It also facilitates to reduce the budget deficit in an economy. Another benefit of FDI is that it reduces external debt and at the same time adds the value of human resources because it provides the services and training to humans. Every country has scarce resources due to which they need FDI that proves beneficial to one country. Many empirical studies prove that FDI serves as mean of exchange from one country to another country. It transfers usually technology and knowledge (Dunning and Hamdani 1997). ${ }^{8}$

Rest of paper is planned as section two provide literature review, section 3 provides the conceptual framework, section 4 describes research design, data collection and its sources, section 5 provides empirical results, section 6 shows conclusion of the study and at the end references are given.

\section{Objectives of Study}

The main purpose of this study is to build up a model for Pakistan's economy (where circumstances are not good for foreign direct investment) by using FDI, population growth, external debt and GDP as macroeconomic indicators. Main objective of this study is that

- How FDI, population growth and external debt affect GDP?

- What changes will take place?

\section{Problem Statement}

We know that when FDI increases, the economic growth in the economy is also increases at the same time. The problem is to analyze the relationship of FDI, population growth and external debt with GDP. Because circumstances of Pakistan now a days are very critical and foreign investors are not ready to invest in our economy.

\section{Research Questions}

- Does there exist a relationship between GDP and FDI?

- Does there exist a relationship between GDP and population growth?

- Does there exist a relationship between GDP and external debt?

- How these variables effect the GDP?

\section{Literature Review}

Kunle and Oluwafolakemi (2014) examined the impact of foreign direct investment on Nigerian economic growth by using time series data from 1999 to $2013 .{ }^{9}$ Regression, OLS estimation technique, is used for estimation of time series data. When economic

${ }^{8}$ Dunning, J., \&Hamdani, A. (1997). The new globalism and developing countries. Tokyo; New York: United Nations University Press

${ }^{9}$ Kunle, M. A., S.O, Olowe. and Oluwafolakemi, F. O. (2014). Impact Of Foreign Direct Investment On Economic Growth Of Nigerian Economic Growth. International Journal Of Academic Research In Business And Social Sciences $4(8)$ 
growth of any country increases then FDI also increases in that economy. For growing more there is a need to maintain the economy in well-mannered way, and political conditions of the economy should be stable, infrastructure of the country should be strong, government of that economy should be based on responsibility, lucidity, effective and capable resource. Moreover, there is a need for government in Nigerian economy to liberalize the foreign sector. To encourage the FDI in Nigerian economy hurdles such as import and export tax duties and leviesshould be removed.Foreign investors canbe encouraged through discouraging such barriers.

Younas et.al. checked the effect of FDI on the economic development of Pakistan. This study used data ranges from 2000 to 2010 by using the least square methods of simultaneous equation. In this study GDP is used as dependent variable and FDI, exports, domestic investment and political instability are used as independent variable. This study concludes a positive relationship of economic growth with FDI. ${ }^{10}$ Luenta (2012) studied the relationship of FDI on economic growth by means of empirical and theoretical evidences. It is a literature review study analyzed by empirically and theoretically by using correlation and regression models, variance, OLS methods, stationary and granger causality test. This study found great wiles to maintain the important effect of foreign direct investment on the economic development of a country through different channels; human capital, transfer of technology, expand of monetary market and export volume etc. ${ }^{11}$

Xiaohong (2009) conducted a study on GDP and FDI in China. He gathered data from 1985 to 2008 to find benefits of using FDI and its impact on GDP in China. He used variables gross domestic product and foreign direct investment. He used Linear Regression Model for empirical analysis of data and proved that FDI has positive effect on economic development of China. It is also proved empirically that China's condition for using FDI is better than other countries in the world. ${ }^{12}$ China is an emerging nation that has developed rapidly. It is true that foreign capitals are gift from foreign investors, which leaves positive effect on economy.

India is also one of the growing nations in Asia. After China, India developed more rapidly than other countries in Asia. Inflow of FDI in India as compared to other countries is rising day by day. Ray ${ }^{13}$ (2012) in his study examined the causal association between FDI and economic growth of India for the period of 1990 to 2010. The results of this study revealed that FDI has positive impact on economic growth. There exists long run equilibrium between foreign direct investment and GDP which is estimated through Johanson Cointigration estimation technique. ${ }^{14}$ Roy and Mandal (2012) ${ }^{15}$ by

\footnotetext{
${ }^{10}$ Younas, H. S., Sohail, A., and Azeem, M. (2014). Impact of FDI on Economic Growth of Pakistan. World Journal of Economic and Finance, 1(1), 002-005

${ }^{11}$ Luenta(2012) "analysis of relationship between FDI and economic growth; a literature review study" the usv annals of economics and public administration, volume 12, issue 1(15), (2012)

${ }^{12} \mathrm{Ma}$, Xiaohong, Op.cit.

${ }^{13}$ Ray, S. (2012). Impact Of Foreign Direct Investment And Economic Growth Of India; Cointigration Analysis. Advances In Information Technology And Management, 2 (1)

${ }^{14}$ Hjalmarsson, E. and Osterholm, P. IMF Working Paper, WP / 07/141, (June 2007)

${ }^{15}$ Roy, S., and Mandal, K. (2012). Foreign Direct Investment and Economic Growth: An Analysis of Selected Asian Countries.Journal of Business Studies Quarterly, 4 (1), 15-24
} 
using penal data inspect the effect of FDI on GDP growth for selected Asian countries. The main aim of this research is to empirically examine the effect of FDI on GDP growth for selected Asian countries. Such selected countries are China, India, Sri Lanka, and Phillipine, Indonesia and Singapore and Malaysia. This study shows that economic growth can increase FDI in most of the above mentioned countries. Growth led foreign direct investment is much more important than FDI led growth. ${ }^{16}$ Granger Causality test has been applied to check the causality relationship. There exists a bidirectional relationship between the variables of study.

Imoudu (2012) ${ }^{17}$ investigated the association of FDI with economic growth of Nigerian economy by using data from year 1980 to 2009. Johnson Cointigration test and Vector Error Correction methodology has been applied for analysis. The results of Johansen Cointigration test technique show the impact of foreign direct investment on real economic growth in Nigerian economy. Suchreal economic factors are agriculture, mining, and manufacturing. The recommendations of the study are that the investment environment in Nigerian economy should be enhanced through strong security system, because security reasons are the main hurdles for investors to invest in one economy and good security system increases the confidence of investors in one economy. Furthermore, to remove or overcome the hurdles in an economy, economic and foreign sector should be liberalized. Furthermore all those things which prove unfavorable for exports or discourage the exports of the economy should be minimize or removed if possible. These barriers include arbitrary tariffs; import and export duties and levies duties etc.

Saqib, et.al. examine the impact of FDI on economic growth of the host country. ${ }^{18}$ The time series data has been used for this and study spanned over 1981 to 2010. GDP in this study is used as dependent variable. On the other hand FDI with four other variables including external debt, trade, inflation and domestic investment are used as independent variables. This study concluded that foreign investment has negative and domestic investment has positive impact on the Pakistan's economic performance. On the other hand, the nation's external debt, trade and inflation have negative impact on its GDP. Gudaro (2012) ${ }^{19}$ conducted a study to observe a relationship among GDP growth performance and historical trend of FDI and CPI in Pakistan for a period ranging from 1981 to 2010. This research study has used GDP as dependent variable and CPI and FDI as independent variables. The results of the study are that GDP had positive and significant correlation with foreign direct investment and has negative and significant association with inflation or CPI.

In recent years, political instability and terrorism are major problem in Pakistan. These problems have affected FDI adversely that leads to lower GDP in Pakistan. GDP ratio

\footnotetext{
${ }^{16} \mathrm{https}: / /$ en.wikipedia.org/wiki/Granger_causality (accessed in June 2016)

${ }^{17}$ Imoudu, E. C. (2012). The Impact of Foreign Direct Investment on Nigeria's Economic Growth; 1980-2009: Evidence from the Johansen's Co-integration Approach. International Journal of Business and Social Science, 3 (6), 122-134

${ }^{18}$ Saqib, N., Masnoon, M., and Rafique, N. (2013). Impact of Foreign Direct Investment on Economic Growth of Pakistan. Advances in Management \& Applied Economics, 3(1), 35-45

${ }^{19}$ Ibid.
} 
has declined in Pakistan in recent years as compare to last few years. This fall occur due to many reasons such as political instability and terrorism which created insecurity for investors. Moreover, investors withdraw their investment from such country and made their investment in some other countries where such conditions are in favor of investors. Zeb, et.al. ${ }^{20}$ analyzed the impact of FDI on GDP of Pakistan by using the time series annual data for the time period 1972- 2013. This study has used GDP as explained variable whereas FDI, political instability and terrorism are used as explanatory variables. Empirically proved that FDI had positive impact on GDP but terrorism and political instability had reverse effect on GDP and FDI. Gaikwad, et.al., ${ }^{21}$ examined the impact of FDI on India's economic growth. They used time series annual data for the period from 1990 to 2006 and found positive correlation between these variables. Louzi and Abadi (2011),Imoudu (2012) ${ }^{22}$ examined the effect of FDI on real economic growth of Jordan and Nigeria respectively by using time series data. Both these studies also confirm the positive relationship among FDI and economic growth.

Thuku, Paul and Almadi(2013) ${ }^{23}$ investigated the impact of population growth on Kenya's economic growth. This study used VAR estimation technique by using annual data from year 1963 to 2009 . This study shows that there exists a significant as well as positive relationship between population growth and Kenya's economic growth. This means that increase in population may result in economic growth.

Theoretically, it is proved that FDI and GDP are positively related to each other. FDI proves beneficial to an economy. Higher FDI leads to higher GDP growth rate in an economy because it has positive relation with GDP. On the other hand external debt has negative effect on GDP of economy because the increased burden of external debt on an economy results in GDP fall.

\section{Theoretical Framework}

In this study GDP is used as dependent variable while population growth, FDI and external debt are used as independent variables.

\section{Operational definitions}

I. GDP:GDP has been used as a proxy for the economic growth of a host country. This indicates the monetary worth of all final goods and services, such goods and services produced within the boundaries of an economy in a given period.

II. FDI: Graham(1995) says that "when there take place a change in net value of investment in host country where investors belong to another country and the

\footnotetext{
${ }^{20}$ Zeb, N., Qiang, F., \&Rauf, S. (2013). Role of Foreign Direct Investment in Economic Growth of Pakistan. International Journal of Economics and Finance, 6(1), 32-38

${ }^{21}$ Gaikwad, P. S., and Fathipour, G. (2013). The impact of foreign direct investment on gross domestic production in India. Information Management and Business Review, 5(8), 411-416

${ }^{22}$ Louzi, B., and A. Abadi, (2011). The Impact of Foreign Direct Investment on Economic Growth in Jordan, IJRRAS- International Journal of Research and Reviews in Applied Sciences, 8(2), 253-258.

${ }^{23}$ Thuku, G. K., Paul, G., \&Almadi, O. (2013). The Impact of Population Change on Economic Growth in Kenya. International Journal of Economics and Management Sciences, 2(6), 43-60
} 
management of such enterprise is under the supervision of these foreign investors". ${ }^{24}$ FDI is the controlling ownership of business venture in one economy from another country's entity. FDI contains in one country mergers and acquisition, new facilities, lending money and reinvesting savings. Foreign Direct Investment is necessary and important predictor of the economic growth. ${ }^{25}$ Foreign direct investment is used as the proxy of total direct investment in U.S dollars.

III. External debt: external debt is an amount of money borrowed by one party in one country from another party in other country. An extremely obliged economy is apparent to be in problem. ${ }^{26}$

\section{Population growth}

Increase in number of individuals in the population is called population growth. When these number of individuals increases in a given period of a time as compare to initial population, it is called population growth rate.

\section{Determination of economic indicators}

\begin{tabular}{|l|l|l|l|}
\hline Variables & $\begin{array}{l}\text { Expected } \\
\text { Signs }\end{array}$ & Proxy & Sources \\
\hline $\begin{array}{l}\text { DV's } \\
\text { GDP }\end{array}$ & & $\begin{array}{l}\text { Used as proxy of } \\
\text { Economic growth }\end{array}$ & World bank \\
\hline $\begin{array}{l}\text { IV's } \\
\text { FDI }\end{array}$ & + & Used as proxy of FDI inflow & World bank \\
\hline $\begin{array}{l}\text { Population } \\
\text { growth }\end{array}$ & + & Used as proxy of population & World bank \\
\hline EXTDEBT & - & Used as Proxy of external debt & $\begin{array}{l}\text { World bank, } \\
\text { economic affair } \\
\text { division and state } \\
\text { bank of Pakistan }\end{array}$ \\
\hline
\end{tabular}

${ }^{24}$ Graham, E.M. (1995). Foreign Direct Investment in the World Economy. IMF World Economic and Financial Survey. 120-135

${ }^{25}$ 25. Kowalski, Elizabeth, "Determinants of Economic Growth in East Asia: A Linear Regression Model" (2000). Honors Projects. p.74. http://digitalcommons.iwu.edu/econ_honproj/74

${ }^{26}$ Ibid. 
Fig\#3.1

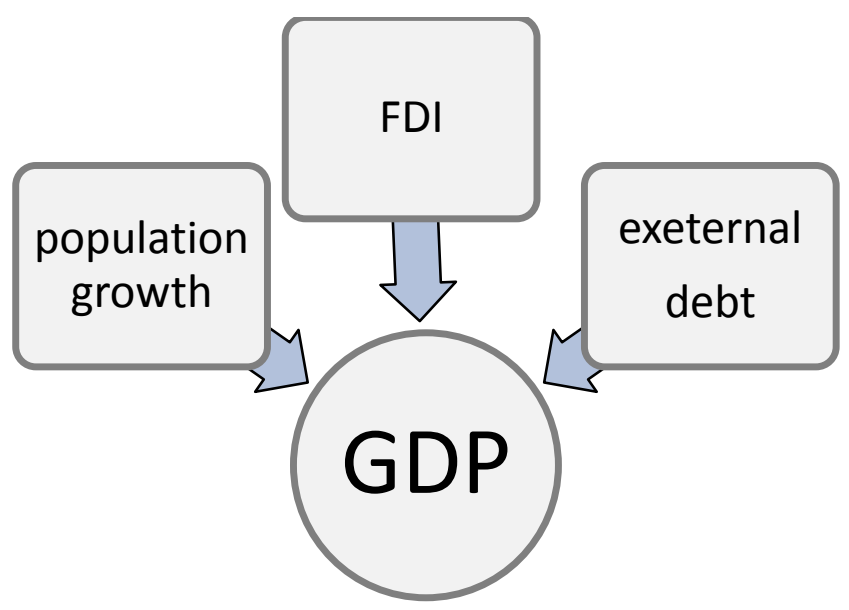

\section{Hypothesis}

$>$ There is a positive correlation between gross domestic product and FDI

$>$ There is a positive correlation between gross domestic product and population growth

$>$ There is a negative correlation between gross domestic product and external debt

\section{Methodology}

\section{Data and Its Sources}

This study uses secondary time series annual data for sample period 1980-2014. For this study data has been acquired from federal bureau of statistics, annual reports of state bank of Pakistan, Planning commission of Pakistan, Economic Survey of Pakistan, Government of Pakistan, and World Bank.

The following regression equation has been used to measure relationship between GDP, FDI, External debt and population growth.

$$
\mathrm{GDP}_{\mathrm{t}}=\beta 0+\beta_{1} \mathrm{FDI}_{\mathrm{t}}+\beta_{2} \text { population }_{\mathrm{t}}+\beta_{3} \text { ExtD }_{\mathrm{t}}+\varepsilon_{\mathrm{t}}
$$

In above-mentioned equation, $\mathrm{t}$ in subscript shows the time series data. On the left side of equation, GDP is used as a dependent variable and on the right side independent variables exist. $\beta 0$ shows the intercept and $\beta_{1}, \beta_{2}$, and $\beta_{3}$ show the slopes of independent variables. At the end $\varepsilon_{t}$ shows the error term.

\section{Statistical Tools}

In this model, multiple regression estimation technique is used to determine the impact of FDI, population growth and external debt on GDP growth of the country. In this study the methodology for getting empirical results is least square method. Moreover 
ADF test to check unit root, Heteroscedasticity White test and Breusch-Godfrey Serial Correlation LM test have been applied to fix validity and reliability of data.

\section{Empirical Results}

\section{Unit Root Test}

The Augmented Dickey Fuller test has been used to test unit root in time series data. The results are given in table 1 .

Table 1. Augmented Dicky -Fuller (ADF) test on the first difference for staionarity of data for the PHCR, ECELF, ECRW and EFFEC variables (1980-2014).

\begin{tabular}{|l|l|c|c|c|l|}
\hline \multirow{2}{*}{ Variables } & \multirow{2}{*}{$\begin{array}{c}\text { First } \\
\text { Difference }\end{array}$} & \multicolumn{3}{|c|}{ MacKinnon critical values } & \multirow{2}{*}{ Decision } \\
\cline { 3 - 5 } & & $1 \%$ & $5 \%$ & $10 \%$ & \\
\hline GDP & -5.806581 & -3.646342 & -2.954021 & -2.615817 & $\mathrm{I}(1)$ \\
\hline FDI & -5.258472 & -3.646342 & -2.954021 & -2.615817 & $\mathrm{I}(1)$ \\
\hline EXTDEBT & -4.155876 & -3.646342 & -2.954021 & -2.615817 & $\mathrm{I}(1)$ \\
\hline EFFEC & -4.586779 & -3.646342 & -2.954021 & -2.615817 & $\mathrm{I}(1)$ \\
\hline
\end{tabular}

Note: null hypothesis about the time series data variables is that the series contains unit root, or non-stationary. The critical values have been used to accept or reject null hypothesis. SIC criteria ranging from lag zero to lag two have been used for selection of lag length.

The results indicated in table 1 show that all the variables have stationarity at the first difference. This indicates that all variables have integration of order one i.e., I (1).

\subsection{Regression Equation Results:}

Table 2. Regression results of GDP, FDI, EXTDEBT, and POPULATION

\begin{tabular}{|l|r|r|r|r|}
\hline Variables & \multicolumn{1}{|l|}{ Coefficients } & Std.error & \multicolumn{1}{l|}{ t-statistics } & \multicolumn{2}{l|}{ Prob } \\
\hline C & 10.70454 & 2.127026 & 5.032633 & 0.0000 \\
\hline FDI & 0.010266 & 0.039485 & 0.259986 & 0.0296 \\
\hline EXTDEBT & -0.124165 & 0.225570 & -0.550451 & 0.0000 \\
\hline Population & $1.00 \mathrm{E}-08$ & $1.75 \mathrm{E}-09$ & 5.714775 & \\
\hline R-squared & 0.961807 & Durbin Watson & 1.854010 & \\
\hline
\end{tabular}


Findings of regression equation show that there exist a positive link between GDP and FDI. The value of FDI is 0.010266. Zeb, Qiang and Rouf (2013) analyzed the impact of FDI on GDP of Pakistan and found a positive relationship between FDI and GDP of Pakistan's economy. Second variable of this study also shows the same result as previous studies shown that there is a negative relationship between external debt and GDP of an economy (Saqib, Masnoon and Rafique, 2013). The coefficient value of external debt is -0.124165 . Negative sign shows the negative relationship between GDP growth and external debt. Third independent variable population growth haspositive relationship with economic growth. The coefficient of population growth is $1.00 \mathrm{E}-08$. Thuku, Paul and Almadi (2013) proved the positive relationship of population growth and GDP growth of Kenya.

This model has a good R-square because the value of R-square is 0.961807 . It means that $96 \%$ variation in dependent variable is due to independent variables while only $4 \%$ variation is due to other variables. Durbin Watson is also in rang. The value of Durbin Watson is 1.854010 .

\section{Residual Diagnostic Test}

\section{Serial Correlation}

Breusch-Godfrey Serial Correlation LM test has been applied to check autocorrelation. Hypothesis for serial correlation test are developed for this study as:

$\mathrm{H}_{\mathrm{o}}=$ there is no auto correlation in data

$\mathrm{H}_{1}=$ there is an autocorrelation in data

Table 3. Breusch-Godfrey Serial Correlation LM Test:

\begin{tabular}{|l|l|l|l|}
\hline F-statistic & 1.847386 & Prob. F(2,28) & 0.1764 \\
\hline Obs*R-squared & 3.872455 & Prob. Chi-Square(2) & 0.1442 \\
\hline R-squared & 0.113896 & Durbin-Watson stat & 1.907354 \\
\hline
\end{tabular}

The $\mathrm{p}$ value in the above table indicates insignificant results. It means that there is an absence of auto-correlation. The results reject the alternative hypothesis in the favor of null hypothesis. So we are happy about the model and it proves the validity and reliability of the data collected for this sample study. 


\section{Normality Test}

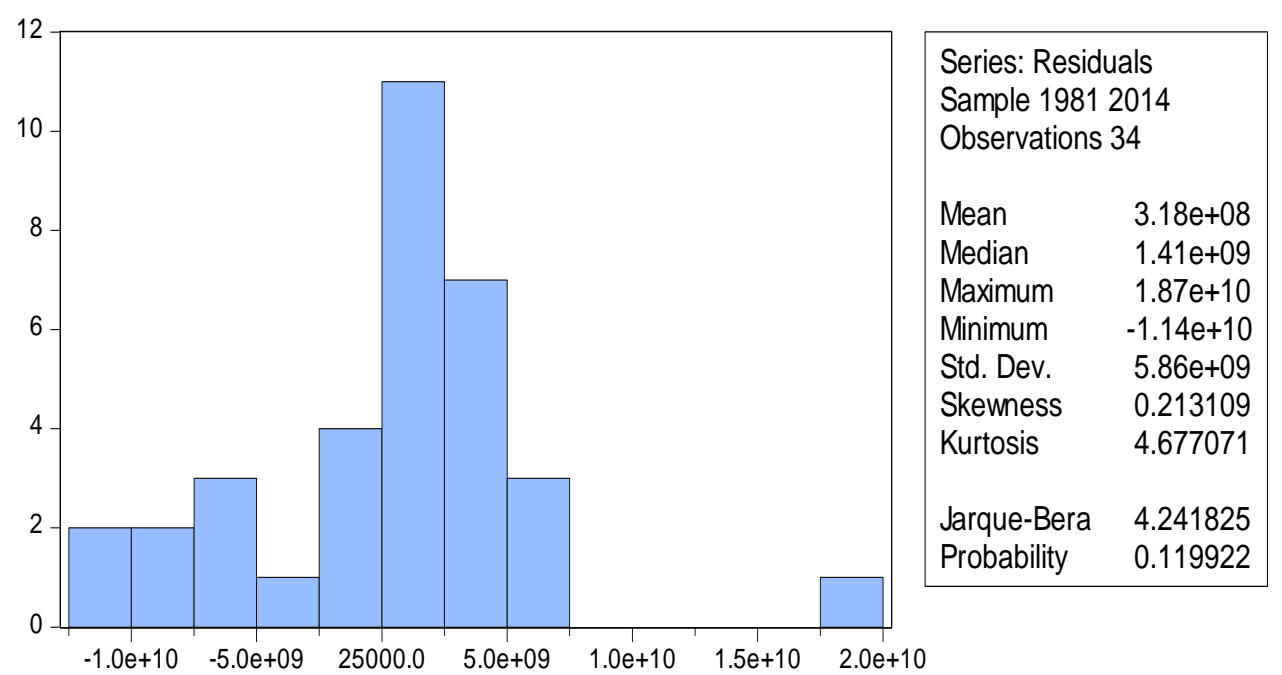

Jarque-Bera normality test has been used to verify the validity and reliability of the model. The $\mathrm{p}$ value $(0.11992)$ indicates that data is normally distributed because its $\mathrm{p}$ value is more than five percent.

\section{Heteroscedasticity Test}

The White test has been used to check the heteroscedasticity in the data. The hypothesis about heteroscedasticity are

$\mathrm{H}_{0}=$ there is no Heteroscedasticity in the data

$\mathrm{H}_{1}=$ there is Heteroscedasticity in the data.

Table 4:Heteroscedasticity White Test

\begin{tabular}{|c|c|c|c|}
\hline F-statistic & 3.847386 & Prob. F(2,28) & 0.45764 \\
\hline Obs $*$ R-squared & 1.872455 & Prob. Chi-Square(2) & 0.56442 \\
\hline
\end{tabular}

The $p$ value in the above table indicates insignificant results. It means that there is no heteroscedasticity in the data. The results reject the alternative hypothesis in the favor of null hypothesis. So we are happy about the model. 


\section{Conclusion}

This study has empirically analyzed the effects of FDI, population growth and external debt on GDP growth of Pakistan by using time series annual data for time period from 1980 to 2014. Findings of this study show a positive correlation of FDI with GDP growth. As theoretically, it is proved that FDI and GDP are positively related to each other. And now empirically it is proved true. External debt has negative effect on economic growth of Pakistan. This study empirically proved that external debt and economic growth have negative relationship. Empirically it is also proved that there exists a positive link between GDP and population growth.

\section{Recommendations}

Pakistan is a developing country where circumstances are not good for foreign direct investment. Pakistan's economy also bears the troubles of debt burden which is the big problem for the economic growth of an economy. Government should create favorable conditions for investors to attract investors. In this way FDI will increase in the country and GDP will grow more rapidly. On the other hand, government should minimize the external debt burden in the country. This will be only possible when external debt will be used only for development expenditures. In our country, debt is used for meeting non-developmental expenditures. Due to this reason, economy bears problem of deficit. Moreover there is a need to educate the growing population technically for their positive contribution in the economic growth of economy.

\section{Bibliography}

Dunning, J., \& Hamdani, A. The new globalism and developing countries. Tokyo; New York: United Nations University Press, 1997.

Gaikwad, P. S., and Fathipour, G. (2013). The impact of foreign direct investment on gross domestic production in India. Information Management and Business Review, $5(8)$.

Graham, E.M. (1995). Foreign Direct Investment in the World Economy. IMF World Economic and Financial Survey.

Imoudu, E. C. (2012). The Impact of Foreign Direct Investment on Nigeria's Economic Growth; 1980-2009: Evidence from the Johansen's Co-integration Approach.

International Journal of Business and Social Science, 3 (6).

Kothare, R. (1999). Does India's Population Growth Has A Positive Effect on Economic Growth?Social Science 410.

Kowalski, E. (2000). "Determinant of Economic Growth in East Asia", Research Honors ProjectIllinois, Wesleyan University. 
Kunle, M. A., S.O, Olowe. and Oluwafolakemi, F. O. (2014). Impact Of Foreign Direct Investment On Economic Growth Of Nigerian Economic Growth. International Journal Of Academic Research In Business And Social Sciences 4 (8).

Louzi, B., and A. Abadi, (2011). The Impact of Foreign Direct Investment on Economic Growth in Jordan, IJRRAS- International Journal of Research and Reviews in Applied Sciences, 8(2).

Ma, Xiaohong (2009). An Empirical Analysis on the Impact of FDI on China'sEconomic Growth. International Journal of Business and Management, 4(6).

Ray, S. (2012). Impact Of Foreign Direct Investment And Economic Growth Of India; Cointigration Analysis. Advances In Information Technology And Management, 2 (1).

Roy, S., and Mandal, K. (2012). Foreign Direct Investment and Economic Growth: An Analysis of Selected Asian Countries.Journal of Business Studies Quarterly, 4 (1).

Saqib, N., Masnoon, M., and Rafique, N. (2013). Impact of Foreign Direct Investment on Economic Growth of Pakistan. Advances in Management \& Applied Economics, 3(1).

Simon, J. L. (1992).Population and Development in Poor Countries. Princeton: Princeton University Press.

Thuku, G. K., Paul, G., \&Almadi, O. (2013). The Impact of Population Change on EconomicGrowth in Kenya. International Journal of Economics and Management Sciences, 2(6).

Waheed, Muhammad, Central Bank Intervention, Sterilization and Monetary Independence: The Case of Pakistan, MPRA Paper 2328, (Germany: University Library of Munich, revised Mar 2007)

Yasin, M. (2001). The debt crises of Pakistan and an optimal fiscal policy. Pakistan Economic and Social Review, 39(2).

Younas, H. S., Sohail, A., and Azeem, M. (2014). Impact of FDI on Economic Growth of Pakistan. World Journal of Economic and Finance, 1(1).

Zeb, N., Qiang, F., \&Rauf, S. (2013). Role of Foreign Direct Investment in Economic Growth of Pakistan. International Journal of Economics and Finance, 6(1). 